\title{
CHEMICAL COMPOSITION AND FATTY ACID PROFILE OF MARINATED MACKEREL (SCOMBER SCOMBRUS) DURING PROCESSING AND STORAGE
}

\author{
Georgi Zhelyazkov ${ }^{1}$, Teodora Popova ${ }^{2}$, Deyan Stratev ${ }^{3}$ \\ ${ }^{1}$ Department of Biology and Aquaculture, Faculty of Agriculture, Trakia University, \\ Students campus, 6014 Stara Zagora, Bulgaria \\ ${ }^{2}$ Department of Ecology and Quality of Animal Production, Institute of Animal Science, \\ 2232 Kostinbrod, Bulgaria \\ ${ }^{3}$ Department of Food Hygiene and Control, Veterinary Legislation and Management, \\ Faculty of Veterinary Medicine, Trakia University, Students campus, 6014 Stara Zagora, Bulgaria \\ georgi_ij@abv.bg
}

\begin{abstract}
The aim of the present study was to determine the changes in the chemical composition and physicochemical properties in mackerel (Scomber scombrus) occurring after marinating and subsequent refrigerated storage of the marinated products in vegetable oils. Samples from raw mackerel, freshly marinated ( 0 day) and stored for 30 and 60 days in sunflower and linseed oil were taken. The chemical composition of the processed fish showed decrease in the content of lipids and increase in the minerals. No considerable changes were observed in the water, dry matter and proteins. The changes observed in the physicochemical parameters were connected with augmentation of the water holding capacity (WHC) and reduction in the water activity due to the higher chloride concentration and lower percentage of free water. Similar trend was observed in the products during storage in the vegetable oils and this led to the relatively long shelf-life of 60 days. The ratios n-6/n-3 and PUFA/SFA were below 4 and about 2 respectively, showing favourable fatty acid profile in the studied fish products.
\end{abstract}

Key words: Mackerel; marination; chemical composition; fatty acids; shelf-life

\section{ХЕМИСКИ СОСТАВ И МАСНОКИСЕЛИНСКИ ПРОФИЛ НА МАРИНИРАНИ СКУШИ (SCOMBER SCOMBRUS) ВО ВРЕМЕ НА ПРЕРАБОТКА И ЧУВАЫЕ}

\begin{abstract}
Целта на ова истражување беше да се определат промените во хемискиот состав и физичко-хемиските својства на скуша (Scomber scombrus), настанати по маринирање и последователно ладење, при чување на маринираните производи во растителни масла. За анализа беа земени проби од сурова скуша, од свежо маринирана (0 денови), и од чувана за време од 30 и 60 дена во сончогледово и ленено масло. Хемискиот состав на преработената риба покажа намалување на содржината на липидите и повисоко количество на минерали. Не беа забележани значителни промени во содржината на влага, сува материја и протеини. Промените забележани во физичко-хемиските својства беа во врска со зголемувањето на капацитетот на задржување на водата (КЗВ) и намалување на активноста на водата поради повисоката содржина на хлориди и понискиот процент на слободна вода. Сличен тренд беше забележан во производите за време на чувањето во растителните масла, што доведе до подолг рок на траење на производите од 60 дена. Соодносите n-6/n-3 и PUFA/SFA беа под 4 и околу 2 соодветно, покажувајќи поволен маснокиселински профил во испитуваните производи од риба.
\end{abstract}

Клучни зборови: скуша; маринирање; хемиски состав; масни киселини; рок на траење

\section{INTRODUCTION}

Sea food is very important for the healthy human diet. It might be consumed raw, frozen, canned, smoked, marinated, cured or dry. Their processing meets different consumers' preferences and minimizes the waste of the seafood. It is very important for prolonging the shelf-life of these foods and hence leads to reduced economical loss [1].

Marinated fish products are made of fresh, frozen, cured or parts of filleted fish after treatment with organic acids, salt, spices, pickles, sauces, 
creams or oils. The aim is to prevent the microbiological and enzyme processes, as well as increase of the nutritional value [2].

Özden (2005) [3] reported for insignificantly lower content of polyunsaturated fatty acids in marinated anchovy and rainbow trout when compared to the fresh fish. Also no considerable difference was found in the content of the saturated and monounsaturated fatty acids in the raw and marinated product. In the fresh and marinated fish the predominant saturated fatty acid is palmytic acid (C16:0) and the most abundant of all is the monounsaturated oleic acid (C18:1 n-9). Large amounts of polyunsaturated fatty acids (PUFA) - eicosapentaenoic acid (20:5 n-3) and docosahexaenoic acid $(22: 6 n-3)$ are also found [3]. Both fresh and marinated fish contain these n-3 PUFA and hence might be favourable for reducing the risk of cardiovascular diseases and certain kinds of cancer [4].

Sea food is an excellent source of nutrients, affecting the health and quality of life. It has been known that $98 \%$ of the total weight of sea food consists of water, proteins and lipids. The ratio between these components differ for the different fish species and the kinds of fish processing [5]. The changes in the nutrients occurring as a result of the processing must be clarified since they are important for the human health [6]. Mackerel is one of the most preferred fish in Bulgaria. It could be consumed as roasted, fried, smoked or marinated.

The aim of this work was to examine the changes in the chemical composition and physicochemical properties of mackerel subjected to marinating and storage.

\section{MATERIAL AND METHODS}

\section{Technological processing of fish}

The processing of the mackerel (Scomber scombrus) was carried out in the fish processing factory of "ECOPROM" Ltd. in Sliven, Bulgaria. The mackerel originated from the Faroer Islands. After defrosting the fish were eviscerated, washed and cut into steaks of $10-15 \mathrm{~mm}$. Batches were prepared, each containing 5 fish. The marinade was prepared according to a recipe of the factory of "ECOPROM" Ltd. and the ratio fish/marinade was $1 / 1$. The fish was marinated for $48 \mathrm{~h}$ at $12^{\circ} \mathrm{C}$. At the end of the process the steaks were drained for an hour, placed into plastic boxes and covered with the necessary quantity of sunflower or linseed oil. Thus prepared the fish was stored in refrigerator $\left(0-4^{\circ} \mathrm{C}\right)$ for 60 days. In order to study the changes occurring in the fish related to the marinating and during the storage, samples were taken from the raw fish, immediately after marinating, at the 30 and 60 days of storage of the marinated fish. All the samples were transported in cooling bag to the Laboratory block in the Trakia University, Stara Zagora. The samples were then minced and homogenized and parts of them were transferred to the Department of Ecology and Quality of Animal Production in the Institute of Animal Science, Kostinbrod for determination of the fatty acid profile.

\section{Physicochemical properties}

The water holding capacity (WHC) of the fish was determined using the method of Grau and Hamm (1953) [7], as described by Zahariev and Pinkas (1979) [8], modified by Petrov (1982) [9]. Water activity of the raw material and the products was determined by HYGROLAB ROTRONIC device. The content of chlorides was determined through argentometric method [10]. Rancidity of the fats was measured by Kreis test.

\section{Chemical composition}

Meat samples were prepared according to AOAC (2006; method 983.18) [11] and subjected to determination of water content using air drying (AOAC, 1997; method 950.46) [12]. Crude protein content was calculated by converting the nitrogen content, quantified by Kjeldahl's method, using an automatic Kjeldahl system (Kjeltec 8400, FOSS, Sweden). Lipid content was determined by the method of Soxhlet, using an automatic system (Soxtec 2050, FOSS, Sweden). Ash content was investigated by incineration in a muffle furnace (MLW, Germany) at $550^{\circ} \mathrm{C}$ for $8 \mathrm{~h}$. Crucibles were brought about the room temperature and weighed.

\section{Fatty acid composition}

Fatty acid composition was analyzed in the Laboratory of Lipid Analysis in the Department of Ecology and Quality of Animal Production, Institute of Animal Science, Kostinbrod. Total lipids of the muscles were extracted according to the method of Bligh and Dyer (1959) [13]. Methyl esters of the lipids, isolated by preparative TLC were 
obtained, using $0.01 \%$ solution of sulphuric acid in dry methanol for $14 \mathrm{~h}$, as described by Christie (1973) [14]. The fatty acid composition of total lipids was determined by GLC analysis using chromatograph C Si 200, equipped with capillary column TR-FAME $(60 \mathrm{~m} \times 0.25 \mathrm{~mm} \times 0.25 \mu \mathrm{m})$ and hydrogen as a carrier gas. The oven temperature was first set at $160^{\circ} \mathrm{C}$ for $0.2 \mathrm{~min}$, then raised until $220^{\circ} \mathrm{C}$ at a rate of $5^{\circ} \mathrm{C} / \mathrm{min}$ and hold for 5 minutes. The temperatures of the detector and injector were $230^{\circ} \mathrm{C}$. Methyl esters were identified, comparing to the retention times of the standard (triarachidin). Fatty acids are presented as percentages of the total amount of the methyl esters identified [14] .

\section{Statistical evaluation}

The statistical evaluation was performed using JMP v.7 software [15]. The influence of marination was examined by one way ANOVA and Dunnet test, as raw fish was considered control group.

\section{RESULTS AND DISCUSSION}

Table 1 presents the results of the chemical analysis of the raw and marinated mackerel during storage (mean and standard deviation). The contents of water, proteins, lipids and minerals in the raw material were in the normal range for the species. The values determined were as follows: water
- $51.17 \pm 4.04 \%$, protein $-17.22 \pm 0.49 \%$, lipids $30.64 \pm 1.84 \%$ and mineral content $-1.08 \pm 0.05 \%$. The lower water content and the higher dry matter content are due to the fact that frozen mackerel was used, after defrosting before the processing.

No significant differences in the water content were observed in the marinated fish. Our results are not in line with those of Rodger et al. (1984) [16] and Özden (2005) [3], who reported that the higher concentration of acetic acid and salt in the tissues of marinated fish leads to lower water content. It could be suggested that our results are due to the freezing of the fish, whereas the authors above have used fresh fish. The protein content was lower in the marinated and stored fish, significant for the mackerel stored 60 days in sunflower oil $(\mathrm{P}<0.01)$. The lipids also decreased as the differences were significant for the fresh marinated fish $(\mathrm{P}<0.01)$, as well as for the mackerel stored in linseed for 30 and 60 days $(\mathrm{P}<0.001)$. This could be explained with the extraction of part of the lipids and their transition into the marinating solution. However the lipids in the fish stored in sunflower oil were higher than those in the fish marinated in linseed oil and this is probably due to the better penetrating ability of the sunflower oil. Considerable increase (over 3\%) was observed in the mineral contents $(\mathrm{P}<0.001)$ for the marinated products except the fish stored for 60 days in the linseed oil. $\mathrm{NaCl}$ in the marinating solution that entered the tissues contributed to this higher content.

Table 1

Chemical composition of raw and processed (marinated) mackerel during storage $(\bar{x} \pm \mathrm{SD})$

\begin{tabular}{lc|c|cc|cc}
\hline \multirow{2}{*}{ Traits } & \multirow{2}{*}{ Raw mackerel } & \multicolumn{3}{|c}{ Marinated mackerel } \\
\cline { 3 - 7 } & & & \multicolumn{2}{|c}{$(30$ days $)$} & \multicolumn{2}{c}{$(60$ days } \\
Water, \% & $51.17 \pm 4.04$ & $50.60 \pm 1.14$ & $48.04 \pm 1.93$ & $50.88 \pm 0.49$ & $49.94 \pm 0.52$ & $49.95 \pm 0.50$ \\
Proteins, \% & $17.22 \pm 0.49$ & $17.62 \pm 0.86$ & $16.14 \pm 0.31$ & $16.84 \pm 0.34$ & $15.73 \pm 0.26^{* *}$ & $16.52 \pm 0.29$ \\
Lipids, \% & $30.64 \pm 1.84$ & $26.55 \pm 0.28 * *$ & $29.50 \pm 1.27$ & $26.51 \pm 0.50 * * *$ & $29.63 \pm 0.92$ & $26.22 \pm 0.39 * * *$ \\
Dry matter, \% & $48.50 \pm 3.72$ & $49.40 \pm 1.14$ & $51.96 \pm 1.93$ & $49.12 \pm 0.49$ & $50.06 \pm 0.52$ & $50.05 \pm 0.50$ \\
Minerals, \% & $1.08 \pm 0.05$ & $4.17 \pm 0.19 * * *$ & $3.69 \pm 0.20^{* * *}$ & $4.25 \pm 0.11^{* * *}$ & $4.40 \pm 0.17^{* * *}$ & $4.11 \pm 0.03$ \\
\hline \hline
\end{tabular}

$* * * \mathrm{P}<0.001, * * \mathrm{P}<0.01$

The changes in the physicochemical properties of the raw and marinated mackerel during storage are presented in Table 2. Water holding capacity of the raw fish was $30.43 \%$. After marinating it decreased to $26.04 \%$. This was due to $\mathrm{NaCl}$ entering in the fish tissues. After the 30 and up to the 60 days of the storage of the marinated fish WHC decreased significantly in all the stored products $(\mathrm{P}<0.01)$. The same relation was observed for the water activity $\left(\mathrm{a}_{\mathrm{w}}\right)$. Its initial value was 0.958 in the raw fish and reached 0.910 after marinating. Towards the 60 days the values of this trait decreased 
and reached 0.880 . The reduced $\mathrm{a}_{\mathrm{w}}$ suppresses the microorganism development that is the main aim of the processing of this kind (marinating and curing).

The chloride content in the marinated mackerel reached $9 \%$ and was in this range though out the storage in the oils. The limit of $9 \%$ was also pointed in the technological specification of the manufacturer. At this concentration of $\mathrm{NaCl}$ in the marinated fish with the addition of the preserving effect of the acetic acid, the product could be stored up to 60 days.

The reaction of Kreis for the rancidity of fat in the fish was negative on 30 and 60 days of the storage in sunflower and linseed oil.

Table 2

Physicochemical properties of raw and processed (marinated) mackerel during storage

\begin{tabular}{lccccc}
\hline \hline Product & $\begin{array}{c}\text { WHC, } \\
\% \pm \mathrm{SD}\end{array}$ & $\begin{array}{c}\text { Water activity } \\
\left(\mathrm{a}_{\mathrm{w}}\right)\end{array}$ & $\begin{array}{c}\text { Temparature, } \\
\mathrm{t}^{\circ} \mathrm{C}\end{array}$ & $\begin{array}{c}\text { Chloride } \\
\text { contents }\end{array}$ & $\begin{array}{c}\text { Rancidity } \\
\text { (Kreis reaction) }\end{array}$ \\
\hline Raw mackerel & $30.43 \pm 3.28$ & 0.958 & 20.9 & ND $^{*}$ & $\mathrm{ND}^{\text {N }}$ \\
Marinated mackerel (0 day) & $26.04 \pm 3.05$ & 0.910 & 20.7 & 9.0 & ND \\
Marinated mackerel in sunflower oil (30 days ) & $21.00 \pm 2.86$ & 0.889 & 18.5 & 8.8 & negative \\
Marinated mackerel in linseed oil (30 days ) & $20.86 \pm 6.27^{* *}$ & 0.883 & 17.1 & 9.3 & negative \\
Marinated mackerel in sunflower oil (60 days) & $19.11 \pm 4.38^{* *}$ & 0.878 & 20 & 8.8 & negative \\
Marinated mackerel in linseed oil (60 days ) & $16.30 \pm 2.62^{* *}$ & 0.880 & 20 & 9.3 & negative \\
\hline \hline
\end{tabular}

$\mathrm{ND}^{*}-$ not detected, $* * \mathrm{P} \leq 0.01$

The fatty acid composition of the raw, fresh marinated and stored fish is showed on Table 3. This analysis was done to characterize the lipid profile of the fish products. The content of the saturated fatty acids in the raw and marinated fish ( 0 day) was $27.71 \%$ and $27.33 \%$ respectively, and it was lower that the reported by Özden (2005) [3] in raw and marinated anchovy $(31.2 \%$ and $33.44 \%$ respectively). The same author reported that content of SFA in raw and marinated rainbow trout was $22.29 \%$ and $24.92 \%$ respectively. In the course of storage of marinated fish, Özden (2005) [3] observed increase in the SFA content where as in our study there was a contrary trend in both mackerel stored in sunflower and linseed oil. The content of SFA on the $30^{\text {th }}$ day of storage was $26.48 \%$ and $24.83 \%$, respectively for the fish in sunflower and linseed oil. On the $60^{\text {th }}$ day of storage the amount of SFA decreased to approximately $23.50 \%$ in both groups of samples.

In our study the content of C14:0 was relatively larger in the raw and in the marinated fish ( $10.86 \%$ and $10.10 \%$ respecitively), as a comparison, in anchovy it was $4 \%$ and in rainbow trout $7.50 \%$ [3]. The quantity of C14:0 in our research decreased throughout the storage, while in the an- chovy and the rainbow trout, it remained unchanged. C16:0 was in amounts of 14.49-15.02\% in the raw and marinated mackerel. These values are in accordance to those determined by Özden (2005) [3] in marinated anchovy and rainbow trout. Both C14:0 and C16:0 are important for the human healthy diet since they are hypercholesterolemic. In this study we found the least content of these fatty acids in the marinated mackerel, stored in linseed oil. The stearic acid (C18:0) that is neutral in regards to the cholesterolemia was determined in the range from $1.42 \%$ to $2.65 \%$, the lowest its percentage was in the raw fish.

The eicosaenoic acid $(\mathrm{C} 20: 1)$ is the most abundant of the monounsaturated fatty acids. Its amount was the smallest in the marinated mackerel stored for 30 days in sunflower oil $-6.29 \%$, and respectively the biggest in the raw mackerel $14.39 \%$. The percentage of $\mathrm{C} 18: 1$ was increased after marinating from $6.70 \%$ to $10.50 \%$. This increase of the percentage continues during the storage in vegetable oils, as the highest it was on the 60 days. C16:1 was within the range of 3.13$4.11 \%$, the highest in the raw fish and the lowest in the mackerel stored 60 day in linseed oil. 
The content of PUFA in the raw mackerel was $47.09 \%$, while in marinated fish it was 44.94\%. The highest content of n-3 PUFA was determined by the considerable amount of C20:5 and $\mathrm{C} 22: 6,30.98 \%$ and $6.40 \%$, respectively. Both fatty acids remain in high quantities after marinating and during the storage of the products.

The mackerel marinated and stored in linseed oil for 60 days displayed very high amount of C18:3n-3 (9.20\%), while in the product stored in sunflower oil for 60 days the content of $\mathrm{C} 18: 2$ was
$8.07 \%$. These contents could be explained by the fatty acid composition of the linseed and sunflower oil. Both $\mathrm{C} 18: 2$ and $\mathrm{C} 18: 3$ are precursors for the synthesis of long chain n-6 and n-3 PUFA. On the other hand despite increasing the PUFA content (mostly n-6) marinating had no negative influence on the ratio $n-6 / n-3$. It remained below the recommended limit of 4 . Also in all the studied products the ratio PUFA/SFA is about 2, while the recommended minimal value is 0.4 [17].

Table 3

Fatty acid profile of raw and marinated mackerel (\%)

\begin{tabular}{|c|c|c|c|c|c|c|}
\hline \multirow{3}{*}{ Fatty acids } & \multirow{3}{*}{$\begin{array}{c}\text { Raw } \\
\text { mackerel }\end{array}$} & \multicolumn{5}{|c|}{ Marinated mackerel } \\
\hline & & \multirow[t]{2}{*}{ (0 day) } & \multicolumn{2}{|c|}{ (30 days) } & \multicolumn{2}{|c|}{ (60 days) } \\
\hline & & & in sunflower oil & in linseed oil & in sunflower oil & in linseed oil \\
\hline C14:0 Myristic & 10.86 & 10.10 & 10.17 & 8.84 & 8.34 & 7.38 \\
\hline C15:0 Pentadecaenoic & 0.60 & 0.18 & 0.59 & 0.49 & 0.46 & 0.33 \\
\hline C16:0 Palmitic & 14.49 & 15.02 & 13.76 & 13.62 & 12.79 & 12.84 \\
\hline C16:1 Palmitoleic & 4.11 & 3.89 & 3.60 & 3.96 & 3.49 & 3.13 \\
\hline C17:0 Margaric & 0.33 & 0.27 & 0.53 & 0.16 & 0.27 & 0.24 \\
\hline C18:0 Steraic & 1.42 & 1.75 & 1.43 & 1.72 & 1.67 & 2.65 \\
\hline C18:1 Oleic & 6.70 & 10.50 & 10.95 & 10.14 & 12.22 & 12.46 \\
\hline C18:2 Linoleic & 1.35 & 2.02 & 5.35 & 3.36 & 8.07 & 6.02 \\
\hline C18:3n-6 $\gamma$-linolenic & 0.36 & 0.13 & 0.13 & 0.13 & 0.13 & 0.13 \\
\hline C18:3n-3 $\alpha$-linoleic & 1.50 & 1.58 & 1.68 & 3.62 & 2.12 & 9.20 \\
\hline C18:4 & 4.71 & 3.87 & 5.88 & 3.61 & 4.03 & 3.51 \\
\hline C20:1 Eicosaenoic & 14.39 & 13.35 & 6.29 & 14.18 & 11.60 & 10.15 \\
\hline C20:2 Eicosadienoic & 0.18 & 0.21 & 0.20 & 0.21 & 0.20 & 0.17 \\
\hline C20:3 Eicosatrienoic & 0.21 & 0.24 & 0.23 & 0.24 & 0.20 & 0.16 \\
\hline C20:4 Arachidonic & 0.11 & 0.39 & 0.13 & 0.11 & 0.13 & 0.12 \\
\hline C20:5 Eicosapentaenoic & 30.98 & 29.22 & 29.81 & 28.78 & 26.34 & 23.12 \\
\hline C22:5 Docosapentaenoic & 1.28 & 1.25 & 1.21 & 1.31 & 1.31 & 1.13 \\
\hline C22:6 Docosahexaenoic & 6.40 & 6.02 & 8.04 & 5.52 & 6.61 & 7.25 \\
\hline SFA & 27.71 & 27.33 & 26.48 & 24.83 & 23.54 & 23.45 \\
\hline UFA & 72.29 & 72.67 & 73.52 & 75.17 & 76.46 & 76.55 \\
\hline MUFA & 25.20 & 27.74 & 20.85 & 28.29 & 27.31 & 25.75 \\
\hline PUFA & 47.09 & 44.94 & 52.67 & 46.88 & 49.15 & 50.81 \\
\hline$n-6$ & 2.22 & 3.00 & 6.05 & 4.04 & 8.73 & 6.60 \\
\hline$n-3$ & 44.87 & 41.94 & 46.63 & 42.83 & 40.42 & 44.21 \\
\hline$n-6 / n-3$ & 0.05 & 0.07 & 0.13 & 0.09 & 0.22 & 0.15 \\
\hline PUFA/SFA & 1.70 & 1.64 & 1.99 & 1.89 & 2.09 & 2.17 \\
\hline
\end{tabular}




\section{CONCLUSIONS}

The analysis of the chemical composition of the processed fish mackerel (Scomber scombrus) showed that during marinating the lipids decreased while the mineral content increased. The contents of water, dry matter and protein do not undergo considerable changes. During storage the water holding capacity of the marinated mackerel stored in vegetable oils increased, whereas the water activity decreased as a result of the augmented chloride concentration and the reduction of the percentage of free water. During the storage this tendency remained as this contributed to the relatively long shelf-life of 60 days. All the products had ration $n-6 / n-3$ below 4 and PUFA/SFA ratio above 0.4 which makes them useful for a healthy human diet.

\section{REFERENCES}

[1] Ünlüsayın, M.: Yılan balığı (Anguilla anguilla Linnaeus, 1766) gökkuşă̆ alabalığı (Oncorhynchus mykiss Walbaum, 1792) ve sudak baliğl (Stizostedion lucioperca Linnaeus, 1758)' nin sicak dumanlama sonrasi lipid ve protein bileşimleri. Ph.D. Thesis, Süleyman Demirel University, Turkey (in Turkish) (1999).

[2] Poligne, I., Collignan, A.: Quick marination of anchovies (Engraulis enchrasicolus) using acetic and gluconic acids. Quality and stability of the end product. Lebensmittel Wissenschaft und Technologie, 33, 202-209 (2000).

[3] Özden, Ö.: Changes in amino acid and fatty acid composition during shelf-life of marinated fish. J. Sci. Food Agric., 85, 2015-2020 (2005).

[4] Heu, M. S., Kim, J. S., Shahidi, F.: Components and nutritional quality of shrimp processing by products. Food Chem., 82, 235-242 (2003).
[5] Sikorski, Z. E., Kolakowska, A., Pan, B. S.: The Nutritive Composition of the Major Groups of Marine Food Organisms. In: "Seafood: Resources Nutritional Composition and Preservation”. ed. Z. E. Sikorski. Gdańsk, Poland, p-p. 29-54 (1990).

[6] Birkeland, S. A., Rørå, A. M. B., Skåra, T., Bjerkeng, B.: Effects of cold smoking procedures and raw material characteristics on product yield and quality parameters of cold smoked Atlantic salmon (Salmo salar L.) fillets. Food Res. Int., 37, 273-286 (2004).

[7] Grau, R., Hamm, G.: Eine einfache Methode zur Bestimmung der Wasserbindung in Muskel. Die Naturwissenschaften, 40 (1), 277-259 (1953).

[8] Zahariev, Z., Pinkas, A.: Methods for slaughter analysis and quality control of the meat. NAIU, Sofia, 1979.

[9] Petrov, Y.: Species and breed related particularities in skeletal muscle microstructure during the ontogenesis of productive animals. DSc thesis, Stara Zagora, 1982.

[10] Anonymous: Bulgarian Institute for Standardization (BDS) 7168: Processed fruit, vegetables and meat. Canned meat and meat-vegetables. Methods for determination of chlorides, 1993.

[11] Official Methods of Analysis of Association of Official Analytical Chemists (18-th edition), 2006.

[12] AOAC: Official Methods of Analysis of Association of Official Analytical Chemists (16-th edition), 1997.

[13] Bligh, E. G., Dyer, W. Y.: A rapid method of total lipid extraction and purification. Can. J. Biochem. Physiol., 37, 911-917 (1959).

[14] Christie, W. W.: Lipid analysis. Pergamon Press. Oxford, 1973.

[15] JMP, v.7 SAS Institute Inc. Cary, NC, 1989-2007 (2007).

[16] Rodger, G., Hastings, R., Cryne, C., Bailey, J.: Diffusion properties of salt and acetic acid into herring and their subsequent effect on the muscle tissue. J. Food Sci. Tech., 49, 714-720 (1984).

[17] Simopoulos, A. P.: Omega-6/Omega-3essential fatty acid ratio and chronic diseases. Food Rev. Int., 20: 77-90 (2004). 